\title{
Take and Give Learning Model Assisted by Non Projection Media Affecting Positive Towards Civics Learning Results
}

\author{
Ni Made Krismantari Yuti ${ }^{1}$, Ni Wayan Arini ${ }^{1}$, Ni Wayan Rati ${ }^{1}$ \\ ${ }^{1}$ Universitas Pendidikan Ganesha, Singaraja, Indonesia \\ *Corresponding author. Email: madekrismantari@gmail.com
}

\begin{abstract}
The low learning results of students in participating in learning Civics became the main problem in this study. This is because the learning model is less varied and the condition of students who are still passive in receiving material in class. Through these problems, this study aims to determine the effect of the take and give learning model assisted by non-projection media on civics learning results. This type of research is a quasy experiment with a post-test only control group design. The population in this study were all students of class $\mathrm{V}$ with a total of 121 students. The sample in this study were 52 students in grade V SD with random sampling technique to determine the sample pairs. Civics learning results data were collected using a multiple-choice test instrument. The analysis technique used is the independent sample t-test. The results showed that there was a significant difference in the take and give learning model assisted by non-projection media on students' Civics learning results ( $\mathrm{t}$-count $=8.057$ with a significance value of $0.000<0.05$ ). Judging from the average score, it is known that the average score of the experimental group learning results is greater than the average score of the control group (21.89> 12.76). It can be concluded that the take and give learning model assisted by non-projection media has a positive effect on Civics learning results.
\end{abstract}

Keywords: Civics Learning Results, Take and Give, Non-projection Media

\section{INTRODUCTION}

Civics is one of the subjects in elementary schools. Civics provides concepts and applications in the form of behavior or character. According to [1] Civics learning in elementary schools is a process that enables humans to have knowledge of character that leads to the values of nationalism. Civics is a subject of strengthening character education. The purpose of the Civics is to increase the awareness and insight of students about their status, rights and obligations in the life of society, nation and state [2]. It means that Civics is an education that contains noble values and norms to increase the awareness and insight of students about rights and obligations. To achieve this goal, Civics learning must be able to stimulate student activity in order to have changes in mental aspects. [3]. So alternative learning is needed that can involve students actively during learning activities [4].

The Civics will be more effective, if there is an interaction between teachers and students. It is a reciprocal relationship between teachers and students, students and teachers, students with other students. Therefore, the learning process must be done in a pleasant atmosphere [5]. It requires a teacher's creativity to create a conducive atmosphere [6]. The purpose of Civics learning is to create good citizens and contributing to understand and implement the rights and obligations of being citizens, to become intelligent, skilled and character citizens.

Based on the above opinion, it can be concluded that Civics learning in Elementary School should be able to improve character, attitudes, and knowledge of students. The teacher must adapt the learning model and media to the material and character of the students. So that students find it easier in the learning process.

The data shows that the average score of students on the midterm test for Civics is very low. The data can be seen as below: 
Table 1. The Average Value of Grade V Elementary School Students in the Midterm Test of Civics

\begin{tabular}{|c|c|c|c|c|c|c|c|}
\hline \multirow{2}{*}{ No } & \multirow{2}{*}{ Name of School } & \multirow{2}{*}{$\begin{array}{l}\text { Number of } \\
\text { Students }\end{array}$} & \multirow{2}{*}{ KKM } & \multicolumn{2}{|c|}{$\begin{array}{l}\text { Number of KKM } \\
\text { Achievements }\end{array}$} & \multicolumn{2}{|c|}{$\begin{array}{l}\text { Percentage of KKM } \\
\text { Achievements (\%) }\end{array}$} \\
\hline & & & & Completed & $\begin{array}{c}\text { No } \\
\text { Completed }\end{array}$ & Completed & $\begin{array}{c}\text { No } \\
\text { Completed }\end{array}$ \\
\hline 1 & SDN 1 Bungaya & 27 & 75 & 11 & 16 & 40.74 & 59.25 \\
\hline 2 & SDN 2 Bungaya & 24 & 76 & 10 & 14 & 41.66 & 58.33 \\
\hline 3 & SDN 3 Bungaya & 25 & 75 & 11 & 14 & 44.00 & 56.00 \\
\hline 4 & $\begin{array}{l}\text { SDN } 1 \text { Bungaya } \\
\text { Kangin }\end{array}$ & 12 & 70 & 5 & 7 & 41.66 & 58.33 \\
\hline 5 & $\begin{array}{l}\text { SDN } 2 \text { Bungaya } \\
\text { Kangin }\end{array}$ & 18 & 70 & 8 & 10 & 44.44 & 55.55 \\
\hline 6 & $\begin{array}{l}\text { SDN } 3 \text { Bungaya } \\
\text { Kangin }\end{array}$ & 15 & 72 & 7 & 8 & 46.66 & 53.33 \\
\hline \multicolumn{2}{|c|}{ Sum } & 121 & - & 52 & 69 & 259.16 & 340.79 \\
\hline \multicolumn{2}{|c|}{ Average } & & & & & 43.19 & 56.79 \\
\hline
\end{tabular}

Based on the table 1 above, it shows that there are 52 students who have achieved the minimum score (KKM) and 69 students who have not reached the minimum score (KKM) of the 121 students. It means that $56.79 \%$ of the students have not reached the minimum score (KKM) and only $43.19 \%$ of the students have reached the minimum score (KKM). Based on the explanation, the percentage of the mean mid-semester score of students who are under the minimum score $(\mathrm{KKM})$ is more than the percentage of students who have reached the minimum score (KKM ). There are several factors that cause low student scores, namely, 1) lack of student curiosity about learning Civics. They only understand the material they get from the teacher and books. 2) Students are not able to apply Civics knowledge in daily life at school and outside of school. 3) students tend to memorize the material presented. 4) The use of learning methods and media by teachers is not optimal. So that students cannot be active and have difficulty in understanding lessons well. So the Civics learning cannot be taught by memorizing only in elementary school [7].

These findings were also confirmed by the statements of teachers and students. The teacher said that, 1) They had often applied the learning method during classroom learning activities, but the teacher realized that the method applied did not work optimally. so that it affects the learning process and results. 2) The material being taught is still based on the textbook. And it is not related to the real life of students, this is because of limited time in preparing for learning. 3) Teachers do not provide opportunities for students to be active in Civics learning so that students cannot develop their prior knowledge in Civics learning. Therefore, the teaching and learning process is not efectivly

Based on the problem above, it is necessary to make improvements in learning to increase students' understanding and mastery of Civics, so that the learning process is able to create a more innovative learning atmosphere. One of the learning models and media that allows each student to play an active role in Civics learning is take and give learning model and non- projection media. The accuracy in choosing the learning model and media has a positive impact on students, especially learning patterns that make students play an active role in learning activities [8].

The take and give learning model is a learning model that stimulates students to be more active and build knowledge that will become theirs [9]. [10] states that in the take and give learning model the role of the teacher in the learning process leads to more as a facilitator and students are expected to master the material through the skills of working in pairs. This is done to determine students' understanding of Civics material. Aqib 2013 revealed, the ability of students to understand the material, namely individual skills to reason, compile and apply alternatives to understand the material. The take and give learning model begins with the formation of groups, in the formation of groups students will be given cards that contain the material to be studied [11]. According to [12] The take and give learning model is a learning model that uses card media. Cards containing learning material that will be obtained from each student are used to help students understand learning material [13].

The advantages of the take and give model are that students will quickly understand the mastery of the material and information that will be obtained from teachers and other students, it can save time in mastering the material, increasing the ability to work together. [14] states that the take and give model can foster selfsensitivity, foster self-confidence, increasing student motivation and improving student learning achievement. [15] also stated that the advantage of take and give is to train students to cooperate and respect the abilities of others. [16] The take and give learning model is learning that has the aim of building a dynamic learning atmosphere, full of enthusiasm and enthusiasm and creating an atmosphere of learning from passive to active, from boredom to cheerful, and to make it easier for students to remember the material. This is supported by several studies that have proven the take and give learning model, namely [17] explaining that the 
application of the take and give method can improve learning results for fourth grade students of SDN 2 Serang. This is evidenced by the results of learning in cycle 1 activities increasing before the pre-cycle and increasing again in cycle 2 . Further research was carried out by [18] which stated that the dependence of grade III students of SDN Kupang 1 on the multiplication table gradually can be minimized by using take and give learning model. This learning model can divert students' attention to the table when working on the multiplication questions given. Then [19] also stated that the results of research using the take and give model were an increase in Mathematics learning results of grade II elementary school students assisted by media drying t-shirts based on educational games.

Based on the findings above, take and give learning model in Civics learning with the help of non-projection media is expected to stimulate students to learn with enthusiasm and enthusiasm [20]. This is in line with the opinion [21] that the motivation that exists in students will appear when there is an urge that causes behavior to achieve learning goals. [22] stated that the media is a very important part of the learning device. Meanwhile [23] states that media is anything that functions to convey information between sources and recipients of information. This will result in an increase in learning results, so non-projection media can be used in the teaching and learning process, both with twodimensional and three-dimensional characters that do not require a projector (projection tool) in learning [24]. The advantages of non-projection media are that they can attract students' attention in the teaching and learning process and make it easier to capture the material provided, easy to obtain, and vary in form [25].

Based on the description above, a study was conducted with the aim of (1) describing the learning results of students who studied with the take and give learning model assisted by non-projection media, (2) describing the learning results of Civics students who learned without using assisted take and give learning non-projection media, and (3) knowing the differences in civics learning results of students who learn with the take and give learning model assisted by non-projection media and students who learn without using the take and give learning model assisted by non-projection media in grade $\mathrm{V}$ students of Elementary school.

\section{METHOD}

The type of research carried out in this study is a quasy experiment quantitative research. Quasiexperimental is a research procedure used to determine the effect of conditions on situations, individual or group behavior. Quasi-experimental is a type of experimental research that has a control group as the control for the implementation of the experiment, but not all variables and conditions outside the experiment can be strictly controlled. The quasi-experimental design used in this study was the post test only control group design. This research consists of three stages, namely the preparation stage, the implementation stage, and the final stage of the research.

Population is a possible value, measuring results, quantitative and qualitative regarding a more complete collection of objects. The population in this study were 121 students of grade V of Elementary school. Sampling is done to determine the part of the population to obtain research data. The technique used is the random sampling technique. Random sampling technique is a random class taking using a drawing system. The sample selection in this study did not randomize individuals but randomized the class. The number of students in the experimental class was 27 while the number of students in the control class was 25 students.

The independent variable in this study is the take and give learning model assisted by non-projection media which is applied to the experimental group and learning without using take and give learning model assisted by non-projection media applied to the control group. The dependent variable in this research is Civics learning results in the cognitive aspects. The data needed in this study is data from the results of student Civics learning. In this study, the method used is the test method. It is a way of obtaining data in the form of a task that must be done by individual or group (testee). The type of test used in this study was an objective test in the form of a regular multiple choice with 4 answer choices ( $a, b, c$ or d) with 30 questions. Firstly, a trial test is conducted to obtain validity, difference power, difficulty index and reliability test before the test is given to students.

After the research data was collected, data analysis was then carried out. The data were analyzed by descriptive statistical analysis and inferential statistical analysis methods. The test requirements were the normality test of the data distribution and the homogeneity test of variance. The aim of Testing the normality of data distribution is to ensure that the sample is normally distributed, so that hypothesis testing can be done. The data that is tested for normality is data on student Civics learning results. The homogeneity test can be done if the data group is in a normal distribution. The homogeneity test is done to show that the differences that occur in hypothesis testing actually occur due to differences between groups, not as a result of differences within groups. Furthermore, to test the hypothesis using the t-test with the polled variance formula.

\section{RESULTS AND DISCUSSION}

\subsection{Results}

The data of this research are Civics learning results data that are taught with the take and give learning model 
assisted by non-projection media and those that are not taught with the take and give learning model assisted by non-projection media. Data obtained of this research is the result of Civics learning using take and give learning model assisted by non-projection media and the result of Civics learning without using take and give learning Table 2. Recapitulation of Data Tendency of Student Civics Learning Results

\begin{tabular}{|c|c|c|}
\hline & Experiment Class & 12.76 \\
\hline Mean & 21.89 & 13.99 \\
\hline Varians & 28.11 & 3.74 \\
\hline Standard Deviation & 5.30 & 21 \\
\hline Maximum Score & 29 & 7 \\
\hline Range & 12 & 15 \\
\hline
\end{tabular}

The table above, shows that the mean of the experimental group is 21.89. While the mean of the control group was 12.76. It means that the mean of the experimental group is higher than the mean of the control group. The variance of the experimental group was 28.11, higher than the variance of the control group, 13.99. The standard deviation of the experimental group was 5,30, higher than the standard deviation of the control group, 3,74 . The maximum score of the experimental group was 29 , higher than the maximum score of the control group, model assisted by non-projection media. The data obtained will be described based on the data tendency, namely, mean, median, mode, standard deviation, variance, range, maximum, and minimum.The results of the data tendency calculation are presented in Table 2.

Table 3. Summary of Normality Test Results of Civics learning test

\begin{tabular}{|c|c|c|c|c|c|c|c|}
\hline & \multirow{2}{*}{ Class } & \multicolumn{2}{|c|}{ Kolmogorov-Smirnova } & \multicolumn{3}{c|}{ Shapiro-Wilk } \\
\cline { 3 - 8 } & & Statistic & df & Sig. & Statistic & df & Sig. \\
\hline $\begin{array}{c}\text { Student } \\
\text { learning } \\
\text { results }\end{array}$ & $\begin{array}{c}\text { Experimental } \\
\text { Learning Results }\end{array}$ & .199 & 27 & .012 & .977 & 27 & .781 \\
\cline { 2 - 8 } & $\begin{array}{c}\text { Control Learning } \\
\text { Results }\end{array}$ & .105 & 25 & .200 & .937 & 25 & .124 \\
\hline
\end{tabular}

Kolmogorov-Smirnov, Shapiro-Wilk and SPSS 20.0 for windows techniques were used to test the normality of data distribution. In the Kolmogorov-Smirnov statistics, the statistical value in the experimental group was $F=0.199$ with a significance number of $0.200>0.05$. The statistical value in the control group $F=0.105$ with a significance value of $0.012>0.05$. Whereas in the Shapiro-Wilk statistic, the statistical value in the
21. The minimum score of the experimental group was 12, higher than the minimum score of the control group, 7. The range score of the experimental group was 18 , higher than the range score of the control group 15.

The results of the post-test were analyzed by using the normality and homogeneity test of variance as a prerequisite for hypothesis testing. And it also showed a homogeneous variant of the two groups.

Table. 4 Data Homogeneity Test of Civics Learning Results

\begin{tabular}{|c|c|c|c|c|c|}
\hline \multicolumn{2}{|c|}{} & Levene Statistic & df1 & df2 & Sig. \\
\hline \multirow{2}{*}{$\begin{array}{c}\text { Student } \\
\text { learning } \\
\text { results }\end{array}$} & Based on Mean & .011 & 1 & 50 & .916 \\
\cline { 2 - 6 } & Based on Median & .031 & 1 & 50 & .861 \\
\cline { 2 - 6 } & Based on Median and with adjusted df & .031 & 1 & 49.809 & .861 \\
\cline { 2 - 6 } & Based on trimmed mean & .012 & 1 & 50 & .913 \\
\hline
\end{tabular}

The homogeneity test of variance in this study uses the Test of Homogeneity of Variances technique. The data distribution can be said to be homogeneous if the significance value is $>0.05$. The significance value is 0.916 . It indicates that the significance value is higher than 0.05 . Thus it can be said that the data from the two groups in Civics learning has homogeneous variants. The experimental group was $\mathrm{F}=0.977$ with a significance number of $0.781>0.05$, the statistical value in the control group was $\mathrm{F}=0.937$ with a significance value of $0.124>$ 0.05 . Therefore, the data on student learning results from the two groups (using and not using take and give learning assisted by non-projection media), were normally distributed. hypothesis testing used in this study is the t test with the polled variance formula with the criteria if tcount $<$ of $t$ table. Then Ho is accepted and $\mathrm{Ha}$ is rejected, and if tcount $>$ from ttable then $\mathrm{Ho}$ is rejected and $\mathrm{Ha}$ is accepted. At the 5\% significance level with degrees of freedom $(\mathrm{dk}=27+25-2=50)$ in order to obtain t table $=3.751$. Based on the results of the t-test analysis, it was 
found that tcount $=8.057$, because tcount $=8.057>$ ttable $=3.751$, then Ho was rejected and Ha was accepted. It means that there is a significant difference between the civics learning results of students who use the take and give learning model assisted by non-projection media and learning without using the take and give learning model assisted by non-projection media of grade $\mathrm{V}$ of Elementary students.

\subsection{Discussion}

This study shows that there is a significant effect on the use of take and give learning model assisted by nonprojection media on the learning results of Civics for fifth grade students of Elementary school. It can be seen from the results of Civics learning achieved by the students. The students' Civics learning results in the experimental group were higher than the students in the control group. The average Civics learning results obtained by the students in the experimental group were 21.89 which is in the high category, while the average civics learning results obtained by students in the control group was 12.76 which is in the medium category. This research also produces a data analysis using the t-test, the t-count is 8,057 and the t-table is 3.751 . The result of the calculation shows that the $\mathrm{t}$-count is higher than the $\mathrm{t}$ table. Take and give is a learning model that involves students with various materials to practice their activeness in the delivery of subject matter. it uses a media card in which contains notes in the form of subject matter. In this model there are steps that become a reference for teachers to do in the learning process, namely; the preparation stage, named, implement, repeat, and celebrate. In this model there are steps that will be able to change the way students learn. it also stimulates students to the condition around the classroom or outside the classroom. The take and give learning model has several principles, according to [26] the principles include: 1) students will be active, 2) all are involved in the learning process, 3) clear learning objectives, 4) feedback occurs in the learning process. According to [27] the take and give learning model has several advantages, namely 1) students will more quickly understand mastery of material and information because they get information from teachers and other students, 2) It can save time in understanding and mastering information.

The results showed that there was a very significant effect on the take and give learning model assisted by non-projection media on the learning results of Civics for fifth grade students of Elementary school in Cluster III, Bebandem District, in academic year of 2019/2020. This can be seen from the Civics learning results achieved by students in both groups, where the experimental group achieved higher, 21.89 compared to students in the control group, 12.76. Besides that, students are more active and more relaxed in the learning process. They are also more involved in the learning process activities. It means that active students are things that indicate learning is going well. Through active learning, students will be directly involved in learning and can make learning more meaningful. This finding is reinforced by [13] which states that the take and give learning model makes students active in teaching and learning activities so that the resulting learning activities are more interactive. The take and give learning model assisted by non-projection media provides more opportunities for students to argue, ask, answer, and exchange information with their friends to get more complete knowledge. This finding is reinforced by [26] which states that learning with the take and give model provides more opportunities for students to seek, find, argue, ask, explore, and manage their own knowledge. Take and give learning model assisted by non-projection media can create a fun learning atmosphere.

Through enjoyable learning, students have a higher interest in learning the material. Fun learning keeps students motivated. This finding is reinforced by [23] which states that the take and give learning model makes students directly involved in the learning process so that it can increase student motivation in the learning process. The learning results in the experimental class at the first meeting showed the enthusiasm of the students in the preparation stage when the teacher gave the card media. The distribution of cards is done to stimulate students to take part in learning. The cards distributed contain concepts about learning material. Each student will receive the card, then at the naming stage, students are asked to strengthen their mastery of the material. In the card there are material concepts that are learned by students. At the implementation stage, students can exchange information with other students. All students stand and look for pairs to inform each other and each student records the name of the pair on the card. And so on until each participant can give and receive each other's materials. Then students read their work in front of the class. All students are actively involved in the learning process. Thus it makes easier for students to understand the material and information from teachers and other students.

At the next meeting, many students became more active. they respond to each other and share information with their partners. they have many opportunities to interact and exchange information about the subject matter. [28] explained that, learning in pairs has been able to increase the learning motivation of students, so they want to work together with their friends to solve the problems they face. The third meeting until the last meeting, students seemed to be accustomed to taking part in learning by understanding Civics material using card media, then they understand the material contained on the card and can convey the concepts of the material again in front of the class. The activeness of students in the learning process can affect the results of the test on the 
post test. The post-test average score of the experimental group was 21.89 which was included in the high category based on the benchmark reference assessment. Based on the results of the study, the use of take and give learning model had a very significant effect on the experimental class in Cluster III Elementary School, Bebandem District. The research results obtained can be used as a reference in considering the learning model. So that it can get more satisfying learning results than before.

\section{CONCLUSION AND SUGGESTIONS}

The use of Take and Give Learning Model Assisted by Non-Projection Media has a very significant effect on Civics Learning Results for grade $\mathrm{v}$ elementary school students. This can be seen from the average score of Civics learning results of students who use the Take and Give learning model assisted by non-projection media. It is higher than the average score of students who do not use the Take and Give learning model assisted by nonprojection media. Based on the results of this study, it is recommended that teachers who teach in elementary schools should be more innovative in the learning process. Teachers must be able to apply innovative learning models. The principal is expected to provide a policy to apply the Take and Give learning model assisted by non-projection media in other subjects. and for other researchers, this research can be used as a reference.

\section{ACKNOWLEDGMENTS}

This work was supported by Universitas Pendidikan Ganesha Singaraja, Fakultas Pendidikan, and Program Studi PGSD FIP Undiksha.

\section{REFERENCES}

[1] R. Rodiyana, Penerapan Metode Pembelajaran VCT (Value Clarification Technique) untuk Meningkatkan Sikap Demokratis Siswa dalam Pembelajaran PKn di Sekolah Dasar, Jurnal Cakrawala Pendas, vol. 1, 2018.

[2] J. W. Dwintari, Kompetensi Kepribadian Guru Dalam Pembelajaran Pendidikan Kewarganegaraan Berbasis Penguatan Pendidikan Karakter, Jurnal Pendidikan Kewarganegaraan, vol. 2, 2017.

[3] A. Pane, M. D. Dasopang, Belajar dan pembelajaran, Jurnal Kajian Ilmu-Ilmu Keislaman, vol. 2, 2017, pp 333-352.

[4] H. Hasnidar and E. Elihami, Pengaruh Pembelajaran Contextual Teaching Learning Terhadap Hasil Belajar PKn Murid Sekolah Dasar, Mahaguru: Jurnal Pendidikan Guru Sekolah Dasar, vol. 1, 2020.

[5] D. Damanhuri, F. A. Bahrudin, W. H. Legiani, and I. N. Rahman, Implementasi Nilai-Nilai Pancasila Sebagai Upaya Pembangunan Karakter Bangsa,
Untirta Civic Education Journal, 2016. DOI: https://doi.org/10.30870/ucej.v1i2.1890

[6] H. Setiyawan, T. N. H. Yunianta, Upaya Meningkatkan Hasil Belajar PKn Melalui Model Pembelajaran Kooperatif Tipe Take and Give Pada Siswa Sekolah Dasar, Jurnal Pendidikan Sekolah Dasar, vol. 2, 2018.

[7] I. P. Diarsa, Pengaruh Model Pembelajaran Two Stay Two Stray Berbantuan Media Visual Terhadap Hasil Belajar IPA Siswa, E-Jurnal PGSD Universitas Pendidikan Ganesha Mimbar PGSD, vol. 5, 2017.

[8] A. Suprijono, Model-model Pembelajaran Emansipatoris, Pustaka Belajar, 2016.

[9] I. S. Udayanti, P. N. Riastini, Penerapan Metode Take And Give Untuk Meningkatkan Hasil Belajar IPA Siswa Kelas IVA, Jurnal Ilmiah Sekolah Dasar, vol. 1, 2017.

[10] I. P. Luritawaty, Pembelajaran Take And Give Dalam Upaya Mengembangkan Kemampuan Pemahaman Konsep Matematis, Jurnal Pendidikan Matematika, vol. 2, 2018.

[11] A. Shoimin, Model Pembelajaran INOVATIF dalam Kurikulum 2013, AR-RUZZ MEDIA, 2017.

[12] M. Mahmudin, Penerapan Model Pembelajaran Take and Give Dapat Meningkatkan Hasil Belajar PKn Materi Peran Indonesia dalam Era Globalisasi, NUSANTARA, vol. 1, 2019.

[13] I. K. N. Wiyasa, I. K. N., and N. L. G. M. P. Dewi, I. G. A. S.Asri, Model Pembelajaran Take and Give Berbantuan Media Grafis terhadap Hasil Belajar PKn SD, Mimbar PGSD Undiksha, 2016.

[14] R. K. D. Septina, Pengaruh Model Pembelajaran Kooperatif Take and Give Terhadap Peningkatan Hasil Belajar Materi Perkalian Siswa Kelas 2 SD N Demangan Yogyakarta, E-Jurnal Skripsi Program Studi Teknologi Pendidikan, 2018.

[15] L. Y. Meda, W. Wakidi, pengaruh model pembelajaran take and give terhadap hasil belajar siswa kelas X. Jurnal Pendidikan Dan Penelitian Sejarah, vol. 8, 2017.

[16] P. Hartami, R. Abdullah, Y. Safitri, Penerapan Model Pembelajaran Kooperatif Tipe Take And Give Pada Materi Minyak Bumi Di Kelas X MAN Sabang, Lantanida Journal, vol. 2, 2017.

[17] S. Upaya Meningkatkan Keaktifan Dan Hasil Belajar Peserta Didik Menggunakan Metode Pembelajaran Take And Give PadMata Pelajaran PKN Kelas IV Semester II SD Negeri 2 Serang, 
Kejajar, Kabupaten Wonosobo Tahun Pelajaran 2016/2017, Jurnal Edukasi Gemilang, vol. 1, 2018.

[18] F. Zakina, A. Lutfiati, Inovasi Model Pembelajaran Take And Give Ditinjau Dari Kesulitan Belajar Siswa Kelas 3 Dalam Materi Perkalian Di SD Negeri Kupang 1, FKIP E-Proceeding, 2018, pp 131-134.

[19] A. Riadin, K. Sari, Penerapan Model Pembelajaran Take And Give Berbantuan Media Menjemur Kaos Berbasis Permainan Edukatif Untuk Meningkatkan Hasil Belajar Matematika Kelas II-A di SDN-5 Panarung Palangkaraya Tahun Pelajaran 2016/2017, Jurnal Pendidikan, vol. 1, 2018.

[20] E. Ambarwati, Y. Yusrin, E. Winaryati, Pengaruh model pembelajaran tipe take and give berbasis pendidikan karakter terhadap motivasi dan hasil belajar siswa dalam pembelajaran kimia, in: Prosiding Seminar Nasional \& Internasional, 2017.

[21] A. Emda, Kedudukan motivasi belajar siswa dalam pembelajaran. Lantanida Journal, vol. 1, 2018, pp 195-202.

[22] R. Rafiudin, M. Basri, Urgensi Penggunaan Media dalam Proses Pembelajaran Bagi Guru Sekolah Dasar Wilayah II Kecamatan Sanrobone Kabupaten Takalar Provinsi Sulawesi Selatan, in: Seminar Nasional Teknologi Pembelajaran Dan Pendidikan Dasar, 2017.

[23] Y. Media, Teknologi Pembelajaran. Prenadamedia Gropup, 2015.

[24] H. S. Dalimunthe, S. Utami, S. Marli, Ketersediaan dan Pemanfaatan Media Non Proyeksi IPS Kelas V Sdn Kecamatan Pontianak Tenggara, Jurnal Pendidikan Dan Pembelajaran Khatulistiwa, vol. 3, 2017.

[25] A. Saisabila, Pengaruh Model Student Facilitator And Explaining Berbantuan Media Visual Non Proyeksi Terhadap Kompetensi Pengetahuan IPA, Indonesian Journal of Educational Research and Review, vol. 1, 2018.

[26] P. E. Pariawan, G. S. Abadi, Pengaruh Model Pembelajaran Take and Give Berbasis Resolusi Konflik terhadap Hasil Belajar IPS Siswa Kelas V SD N 26 Pemecutan, Mimbar PGSD Undiksha, vol. $1,2016$.

[27] R. Mubarokah, Penerapan Model Pembelajaran Kooperatif Take And Give Terhadap Kemampuan Pemahaman Konsep Kelas VII, Jurnal Ilmiah Pendidikan Matematika, 2017.

[28] M. Simbolon, Penerapan Model Pembelajaran Kooperatif dalam Meningkatkan Motivasi Serta
Kreativitas dan Hasil Belajar Siswa di SMP Negeri 5 Tebing Tinggi, School Education Journal PGSD FIP Unimed, 7(3) (2017) 353-362. 